Saša Redžić

Arheološki institut Beograd

Angelina Raičković

Arheološki institut Beograd

Snežana Golubović

Arheološki institut Beograd

904:726.821(497.11)"00/03"

904:739.2(497.11)"00/03"

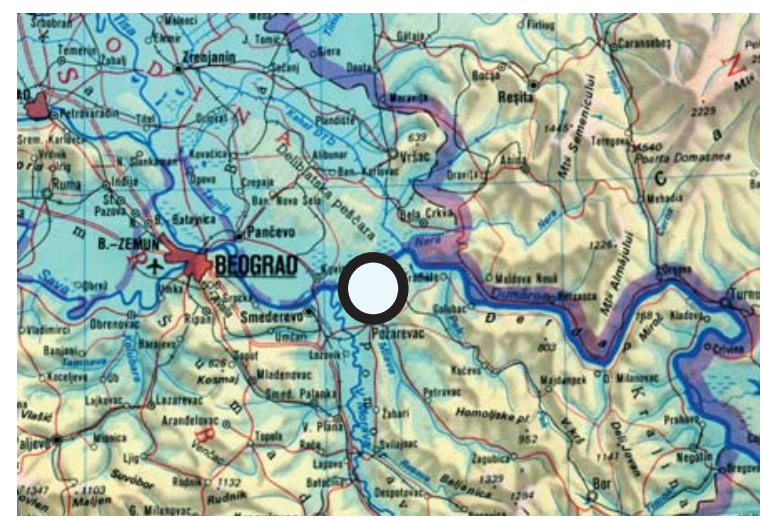

Viminacijum, Stari Kostolac, Srbija

LAT 44o 44'09" / LONG 210 12' 42"

\title{
HRONOLOGIJA VIMINACIJUMSKIH NEKROPOLA U SVETLU PRONAĐENIH FIBULA
}

\begin{abstract}
ABSTRAKT
Viševekovno obitavanje ljudi na teritoriji Viminacijuma je u njegovom neposrednom okruženju uzrokovalo nastajanje nekropola koje se razlikuju kako po periodu svoje upotrebe, tako i po etničkoj pripadnosti stanovništva koje se na njima sahranjivalo.

Dve najdetaljnije istražene nekropole su „Pećine “ $i$, Više grobalja “. Najstarije fibule su nalažene u zapadnom delu nekropole „Pećine “i pripadaju keltskom stanovništvu. Iz ranocarske epohe raspolažemo malobrojnim materijalom. Period od kraja I do sredine III veka predstavlja vreme procvata grada, što se reflektuje količinom nađenog materijala. Najdominantniji tipovi ovog razdoblja su: izrazito profilisane fibule crnomorsko-podunavskog tipa, fibule sa šarnirom slične Aucissa fibulama i kolenaste fibule sa šarnirom. Epohu od sredine III pa do početka IV veka karakteriše izrazito opadanje količine nađenog materijala, kako na nekropolama „Pećine“ $i$,, Više grobalja“ tako i na svim ostalim. T fibule sa šarnirom predstavljaju najbrojniju grupu fibula koja je u upotrebi tokom ovog perioda. Četvrti vek karakteriše upotreba krstastih fibula koje predstavljaju najbrojniji tip na Viminacijumu. Tokom V veka na nekropoli , Više grobalja“ se sahranjuje germanski živalj. Pripadnici germanskih plemena se takođe sahranjuju i na nekropolama ,Više burdelja “ $i$,Lanci“ na kojima su nalažene i starije, rimske fibule. Dominantan tip tokom ovog perioda su fibule sa posuvraćenom stopom.
\end{abstract}

\section{KLJUČNE REČI: VIMINACIJUM, NEKROPOLA, FIBULE, TIP, DATOVANJE.}

Tokom viševekovnog obitavanja ljudi na teritoriji Viminacijuma, u njegovom neposrednom okruženju se formiraju nekropole koje se razlikuju kako po periodu svoje upotrebe tako i po etničkoj pripadnosti stanovništva koje se na njima sahranjivalo.

Dve najdetaljnije istražene nekropole su
„Pećine“ i „Više grobalja“. Obe nekropole su istraživane u periodu koji prethodi izgradnji termoelektrane. Pošto su ove dve nekropole jedna pored druge, a arheološki nalazi veoma slični, neki od istraživača su pretpostavili da se radi o jednoj celini koja je zbog različitih toponima uzetih za imena lokaliteta veštački podeljena na dva loka- 
liteta. Međutim, neke bitne razlike u nađenom materijalu ne podržavaju ovu pretpostavku.

Najstarije fibule su nalažene u zapadnom delu nekropole „Pećine“ i pripadaju keltskom stanovništvu. U ovim keltskim grobovim, datovanim u kraj IV i početak III veka stare ere, ${ }^{1}$ nađene su ukupno 34 fibule.

Iz ranocarske epohe raspolažemo malobrojnim materijalom, što možda podržava mišljenje M. Mirković da je Viminacijum strateški značaj dobio tek za vreme Domicijanove vladavine, kada su Rimljani počeli da vode ofanzivnu politiku prema Dačanima. $^{2}$

Period od kraja I do sredine III veka predstavlja vreme procvata grada, što se ogleda i u količini nađenog materijala. Najveći broj tipova nađenih na Viminacijumu, a koji se datuju u ovaj period prilično su ravnomerno zastupljeni na oba lokaliteta. Jedina bitnija razlika se opaža kod izrazito profilisanih fibula crnomorsko-podunavskog tipa, koje su na lokalitetu „, Više grobalja“ zastupljene sa 11 primeraka, dok ih je na lokalitetu „Pećine“ nađeno tačno tri puta više. ${ }^{3}$ Najdominantniji tipovi ovog razdoblja, pored već pomenutog, su fibule sa šarnirom slične Aucissa fibulama ${ }^{4}$ i kolenaste fibule sa šarnirom, ${ }^{5}$ koje su na ova dva lokaliteta zastupljene sa ukupno 111 primeraka.

Epohu od sredine III pa do početka IV veka, karakteriše rapidno opadanje količine nađenog materijala, kako na nekropolama „Pećine“ i „Više grobalja“ tako i na svim ostalim. T fibule sa šarnirom predstavljaju najbrojniju grupu fibula koja je u upotrebi tokom ovog perioda i ona je na ovim lokalitetima zastupljena sa 27 primeraka. Treba podsetiti da se ovaj tip javlja još u prvoj polovini III veka, te stoga predstavlja prelazni oblik između ove i prethodne epohe.

Četvrti vek karakteriše upotreba krstastih fibula koje, sa 79 otkrivenih primeraka, predstavljaju najbrojniji tip na Viminacijumu. Na lokal-

1. Zotović, Jordović 1990, 2.

2. Mirković 1986, 35.

3. Redžić 2006, 32-46, T. VIII-XII, 65-118.

4. Redžić 2006, 10-20, T. I-VI, 5-39.

5. Redžić 2006, 63-76, T. XVI-XIX, 168-211. itetu „Pećine“ nađeno je 43 primerka, a na „Više grobalja" samo jedan jedini komad. Ova činjenica jasno ukazuje da se nekropola „Pećine“ i dalje koristi dosta često, za razliku od „Više grobalja“ koja još sredinom III veka gubi na značaju. Ovo mišljenje potvrđuje i navod Lj. Zotović, da je na teritoriji nekropole „Više grobalja“ tokom IV veka formirano ruralno naselje. ${ }^{6}$ Pored nekropole „Pećine“ još je samo nekropola „Pirivoj“ sa 15 pronađenih fibula ovog tipa u upotrebi. Na lokalitetu „Pirivoj“ krstaste fibule su nalažene samo u neposrednoj blizini mauzoleja. U istočnom delu ove nekropole, formirane oko komunikacije koja vodi od istočne kapije logora dalje na istok (koja je iskopavanjima i potvrđena), krstaste fibule do sada nisu nađene. Treba pomenuti da se sahranjivanje na lokalitetu „Pirivoj“ obavlja takođe od kraja I veka. Ove dve nekropole zanimljive su još i zbog izuzetno visokog procenta krstastih fibula nađenih u grobovima u odnosu na fibule iz sloja. Na nekropoli „Pirivoj“ on iznosi 86, dok na nekropoli „Pećine“ čak 90 procenata. Ovaj procenat je kod drugih tipova fibula na Viminacijumu neuporedivo niži. Razlog za ovo verovatno leži u činjenici, da se ove dve nekropole od kraja IV veka više ne koriste, te ne postoje mlađi grobovi koji bi svojim ukopom oštećivali grobove sa krstastim fibulama.

Tokom V veka nekropola „Više grobalja“" je ponovo u upotrebi, ali ovoga puta na njoj se sahranjuje germanski živalj. Slična situacija je i sa nekropolom „Više burdelja“ na kojoj se sahranjuju Gepidi i koju je Lj. Zotović datovala u drugu polovinu $\mathrm{V}$ veka. ${ }^{7} \mathrm{Na}$ ovom lokalitetu su nalažene fragmentovane krstaste fibule, pa treba pretpostaviti da postoji i sloj iz kasnoantičkog perioda. Dominantan tip tokom ovog perioda su fibule sa posuvraćenom stopom. Na lokalitetu „Lanci“ nađeno je nekoliko rimskih fibula u sloju. Grobovi istraženi na ovom lokalitetu pripadaju Germanima čija su staništa pronađena prilikom

6. Zotović, Jordović 1990, 2.

7. Zotović 1980, 106. 
istraživanja obližnjeg lokaliteta ,Svetinja“". $\mathrm{Na}$ osnovu nalaza skifata može se reći da na lokalitetu postoji i srednjevekovni sloj, koji je posvedočen na Sopotskoj gredi u čijem se podnožju nalazi lokalitet „Lanci“. Na pomenutoj Sopotskoj gredi tokom XI i XII veka, u okviru bedema ranovizantijskog Biminakiona nastaje Braničevski grad. $\mathrm{U}$ istom periodu južno od njega podignuto je još jedno utvrđenje, čiji nastanak M. Popović datuje u vreme vladavine Jovana II Komnina. ${ }^{9}$

$\mathrm{Na}$ ostalim nekropolama, a to su: „Carine“, „Velika kapija“, „Na rupi“, , Kod bresta“ i „Kod koraba“ (upravo se sada istražuje), sahranjivanje se vrši u periodu od kraja I do sredine III veka. Tipovi koji su na njima nalaženi skoro da se u potpunosti poklapaju sa onima nađenim na lokalitetima „Pećine“ i ,Više grobalja“. Na ovim lokalitetima samo sporadično se javljaju krstaste fibule (skoro isključivo u sloju), što se ne može uzeti kao dokaz da su ove nekropole u upotrebi i posle sredine III veka.

Na osnovu iznetih podataka možemo zaključiti da analizom fibula nađenih na viminacijumskim nekropolama možemo sa dosta sigurnosti utvrditi period njihovog korišćenja. Za preciznije hronološko opredeljenje ovih nekropola neophodna je obrada i ostalih vrsta nalaza, a naročito novca.

\section{RESUME}

\section{Chronology of the Viminacium Necropolis According to the Fibulae}

Dwelling of people at Viminacium and its vicinity for many centuries caused forming of necropoles which were in use in different periods by people of different ethnical origin.

The two best investigated necropoles are certainly those situated at the sites „Pećine“ and „Više grobalja“. The oldest fibulae were found in the western part of the „Pećine“ necropolis,

8. Popović 1987, 34.

9. Popović 1987, 33. belonging to the Celtic population.

The material from the early Empire is small in number, which shows that Viminacium gained its strategic importance only during the reign of Domitianus, when the Romans began their offensive against the Dacians. The time between 1 st and the middle of $3^{\text {rd }}$ century represents the period when the city was blossoming, which reflects itself in the multitude of the material found. The greatest part of the material belonging to this period is rather evenly spread at both sites. The most numerous types are strongly profiled fibulae of the type connected to the Black sea and the Danube valley, fibulae with hinge, very similar to the Aucissa type and knee-shaped fibulae with hinge.

The period between the middle of $3^{\text {rd }}$ until the beginning of $4^{\text {th }}$ cent. is characterized by the decrease of the quantity of the material found, both at „Pećine“ and ,Više grobalja“" necropoles, as well as at all the other necropoles. The most numerous group of fibulae used in this period are the " $T$ " shaped fibulae with hinge.

During $4^{\text {th }}$ cent. the cross-shaped fibulae were in use, which represent the most numerous type at Viminacium. Fourtythree examples were found at „Pećine“, and only one example at, ,Više grobalja“". This fact shows that the „Pećine“ necropolis was still in use, contrary to the necropolis ,Više grobalja“, which lost its importance in the middle of $3^{\text {rd }}$ cent. This hypothesis is confirmed by the fact that during $4^{\text {th }}$ cent. on the necropolis ,Više grobalja“" a rural settlement was formed. Besides the "Pećine" necropolis only the "Pirivoj" necropolis was still regularly in use. At the "Pirivoj" necropolis, the cross-shaped fibulae were found only in the vicinity of the mausoleum. In the eastern part of this necropolis, which was formed by the road leading from the eastern gate of the military camp further on to the east, no cross-shaped fibulae were yet been found. It should be mentioned that the "Pirivoj" necropolis was in use from the end of $1^{\text {st }}$ cent.

Other necropoles, like „Carine“, „Velika kapija“, „Na rupi““, „Kod bresta“ and „Kod 
koraba" (currently being excavated), were in use from the end of $1^{\text {st }}$ to the middle of $3^{\text {rd }}$ cent. Cross-shaped fibulae appear only sporadically at these necropoles, which cannot confirm that these necropoles were in use even after the middle of $3^{\text {rd }}$ cent.

During $5^{\text {th }}$ cent. "Više grobalja“ was in use again, this time by the population of German tribes. They also buried their deceased at the necropoles „Više burdelja“ and „Lanci“, at which older, Roman types of fibulae were found. The dominant type of fibulae in this period are examples with bent foot.

All these data show that one can determine the period of usage of necropoles by analyzing the fibulae found on them, even though the more precise determination would require analyses of other types of archaeological material, especially coins.

\section{BIBLIOGRAFIJA}

\section{Mirković 1968}

M. Mirković, Rimski gradovi na Dunavu u Gornjoj Meziji, Dissertationes VI, Beograd 1968.

\section{Popović 1987}

M. Popović, Svetinja, novi podaci o ranovizantijskom Viminacijumu, Starinar XXXVIII, Beograd 1987, 1-37.

\section{Redžić 2006}

S. Redžić, Nalazi rimskih fibula na nekropolama Viminacijuma, Magistarska teza u rukopisu, Beograd 2006.

\section{Zotović 1980}

Lj. Zotović, Nekropola iz vremena seobe naroda sa uže gradske teritorije Viminaciuma, Starinar XXXI, Beograd 1980, 95-116.

Translated by M. Tapavički-Ilić

\section{Zotović, Jordović 1990}

Lj. Zotović, Č. Jordović, Nekropola ,, Više Grobalja“, Viminacium I, Beograd 1990.

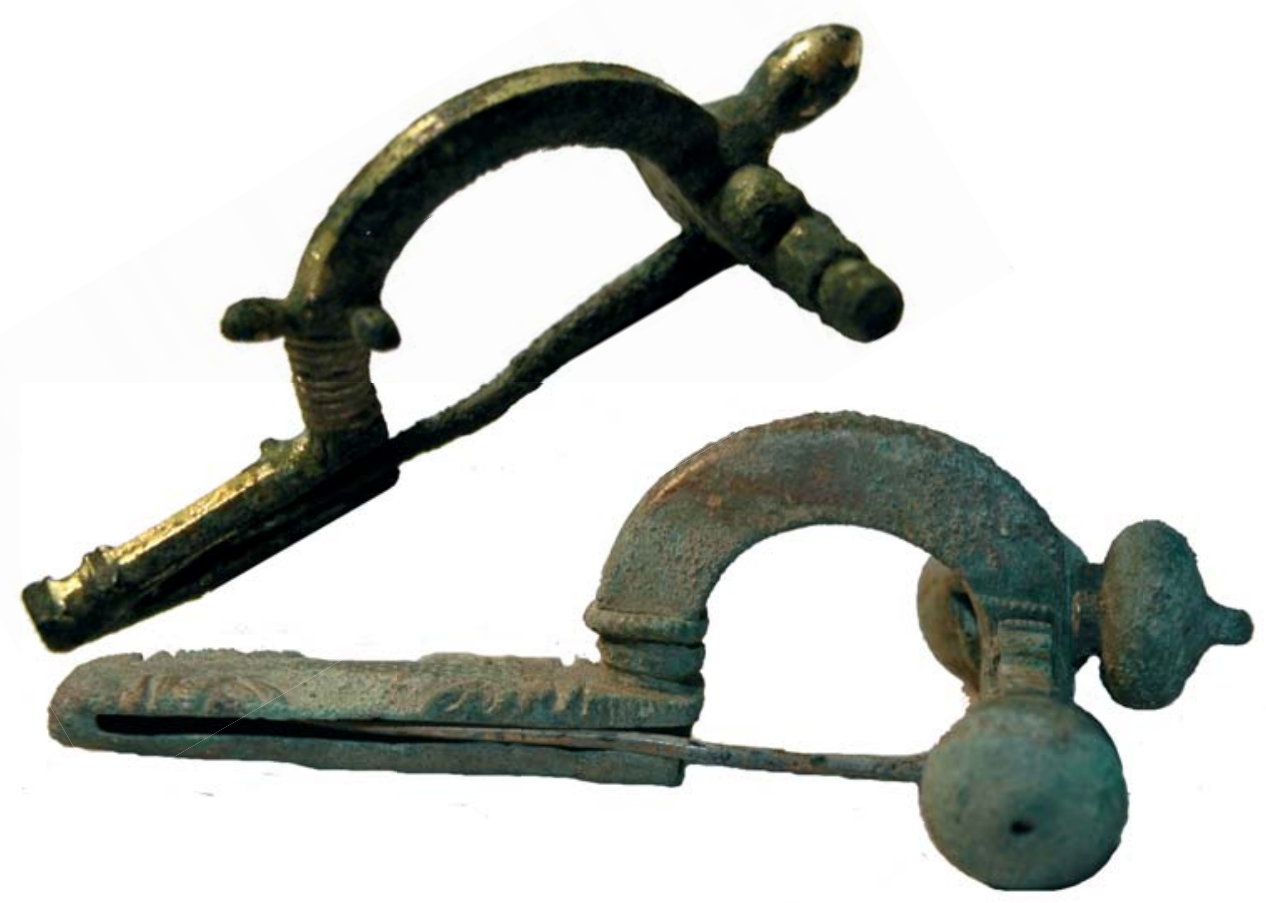

